\title{
The impact of marketing intelligence and business intelligence on acquiring competitive advantages
}

\author{
Ahmad Rahchamani \\ Assistant Professor, Faculty of Management and Accounting, Qazvin Branch, Islamic Azad \\ University, Qazvin, Iran \\ a.rahchamani@qiau.ac.ir \\ Babak Rashidi Ashtiani \\ PhD Student in Marketing Management, Business Dept., Faculty of Management and Accounting, \\ Qazvin Branch, Islamic Azad University, Qazvin, Iran \\ babak.rashidi@qiau.ac.ir \\ Meisam Aminzadeh Vahedi \\ PhD Student in Marketing Management, Business Dept., Faculty of Management and Accounting, \\ Qazvin Branch, Islamic Azad University, Qazvin, Iran \\ dm.aminzadeh@gmail.com
}

\section{Editor Científico: José Edson Lara \\ Organização Comitê Científico \\ Double Blind Review pelo SEER/OJS \\ Recebido em 24.09.2019 \\ Aprovado em 08.11.2019}

\section{(c) (1) (8)}

Este trabalho foi licenciado com uma Licença Creative Commons - Atribuição - Não Comercial 3.0 Brasil 


\begin{abstract}
Companies play an important role as an intermediary link between suppliers (manufacturers and importers) and customers. Relying on expert and efficient human capital, adherence to standards, as well as applying knowledge and technology are the most influential factors in driving a company's goals. One of the new tools, which helps organizations move toward their goals, is the use of marketing intelligence. Therefore, in this study, we try to analyze the impact of marketing intelligence and business intelligence on competitive advantage. The statistical population of this study consists of managers of information technology companies that 200 subjects were sampled. The main tool for data collection is questionnaire. Research findings suggest that marketing information, creativity, IQ and EQ influence marketing intelligence enhancement. Marketing intelligence also affects business intelligence and business intelligence to gain competitive advantage. Overall, this study confirms the relationship between model variables.
\end{abstract}

Keywords: Marketing Intelligence, Business Intelligence, Competitive Advantage, Creativity

\title{
O impacto da inteligência de marketing e da inteligência de negócios na aquisição de vantagens competitivas
}

\section{Resumo}

As empresas desempenham um papel importante como um elo intermediário entre fornecedores (fabricantes e importadores) e clientes. Contando com capital humano especializado e eficiente, a adesão aos padrões e a aplicação de conhecimento e tecnologia são os fatores mais influentes na condução dos objetivos de uma empresa. Uma das novas ferramentas, que ajuda as organizações a alcançar seus objetivos, é o uso da inteligência de marketing. Portanto, neste estudo, tentamos analisar o impacto da inteligência de marketing e da inteligência de negócios na vantagem competitiva. A população estatística deste estudo é composta por gerentes de empresas de tecnologia da informação que foram amostrados 200 sujeitos. A principal ferramenta para coleta de dados é o questionário. Os resultados da pesquisa sugerem que informações de marketing, criatividade, QI e EQ influenciam o aprimoramento da inteligência de marketing. A inteligência de marketing também afeta a inteligência de negócios e a inteligência de negócios para obter vantagem competitiva. No geral, este estudo confirma a relação entre as variáveis do modelo.

Palavras-chave: Inteligência de Marketing, Inteligência de Negócios, Vantagens Competitivas, Criatividade 


\section{El impacto de la inteligencia de marketing y la inteligencia de negocios para obtener una ventaja competitiva}

\section{Resumen}

Las empresas juegan un papel importante como enlace intermediario entre proveedores (fabricantes e importadores) y clientes. Depender del capital humano experto y eficiente, el cumplimiento de las normas y la aplicación de conocimientos y tecnología son los factores más influyentes para impulsar los objetivos de una empresa. Una de las nuevas herramientas, que ayuda a las organizaciones a avanzar hacia sus objetivos, es el uso de la inteligencia de marketing. Por lo tanto, en este estudio, tratamos de analizar el impacto de la inteligencia de marketing y la inteligencia de negocios en la ventaja competitiva. La población estadística de este estudio consiste en gerentes de empresas de tecnología de la información de los cuales se tomaron muestras de 200 sujetos. La herramienta principal para la recopilación de datos es el cuestionario. Los resultados de la investigación sugieren que la información de marketing, la creatividad, el IQ y el EQ influyen en la mejora de la inteligencia de marketing. La inteligencia de marketing también afecta la inteligencia de negocios y la inteligencia de negocios para obtener una ventaja competitiva. En general, este estudio confirma la relación entre las variables del modelo.

Palabras clave: inteligencia de marketing, inteligencia de negocios, ventaja competitiva, creatividad

\section{Introduction}

Marketing and business intelligences are of important issues because business owners can use this intelligence to increase their marketing potential, the extent to which the type of information available can be effective in generating competitive advantage and how this information is provided, the sources of this information, and at what stages this information should be available to the human resources of the company, are unknown. Companies play an important role as an intermediary link between suppliers (manufacturers and importers) and customers. In the present era, the capillary distribution of goods in industrial units has been accepted as an attribute along with other industries and has defined its specialties. Relying on expert and efficient human capital, adherence to standards as well as applying state-of-the-art knowledge and technology is the most influential factors in advancing a company's goals. Nowadays companies are facing constant changes in the sales market, these changes happen so fast that if companies do not prepare to face them in the future, their survival will be at risk and in this competitive environment, market players will need a An effective marketing and business intelligence system is essential not only for marketing executives but for all managers 
at all levels and staffs. One of the new tools that helps organizations move toward their goals is the use of marketing intelligence. We are looking for this research.

Various books published in various fields of marketing so far show that there is no difference between market information, marketing intelligence and marketing research, which has led to many ambiguities. At the international level, researchers have provided ways to access marketing intelligence in the organization, but no specific model has been provided on how to create marketing intelligence in the organization. The purpose of this study is to clarify such ambiguities

\section{Theoretical background and principles of research}

- $\quad$ Business Intelligence:

Business intelligence is a set of concepts, methods and processes that aim not only to reform business decisions but also to support the realization of a company's strategy. The core tasks of business intelligence systems include the intelligent identification, integration, multidimensional analysis and analysis of data obtained from various information sources, including both internal and external sources (Mahmoudi, 2005).

- $\quad$ Competitors Intelligence:

Competitive intelligence is an ongoing effort to evaluate competitors' behavior and capabilities to develop competitive advantage (Adidam et al., 2009).

\section{- $\quad$ Acquiring Competitive Advantage:}

According to J. Keegan, competitive advantage is the increasing attractiveness of a company's offerings to its competitors in terms of customers

Howama believes: The competitive advantage is the differentiation in the characteristics or dimensions of any company that enables it to deliver better services than competitors (better value).

"The competitive advantage is the value the company offers to customers so that those values are higher than the cost of the customer," Porter says. 
Considering the above definitions of competitive advantage, it indicates that the direct relationship between the customer's desired values, the values offered by the firm (in this study, IT companies) and the values offered by the competitors of the firm determine the requirements and dimensions of competitive advantage. If, from the customer's point of view, the comparison of the firm's offered values with those of competitors is more consistent and closer to its intended values and policies, it can be said that the company has a competitive advantage over one or more of its competitors in such a way that this advantage It makes the marketplace company superior to its competitors near the customer and conquering his heart.

One way to acquire lasting competitive advantage is to emphasize the continuous learning of the employees of the organization in order to achieve the organizational goals with maximum effectiveness. Certainly, today's changing environment will not allow organizations to deal with the pressures of competitors' traditional skills, abilities and technologies. Framing and contextualizing learning and training faster than competitors can help the organization move better and faster than competitors. On the other hand, with the improvement and enhancement of the skills of the employees, the needs and demands of the customers are more satisfactorily met, which gives the organization a sustainable competitive advantage.

\section{- $\quad$ Marketing Intelligence:}

Marketing intelligence is the information every day about changes in the marketing environment that helps managers prepare and implement marketing programs. In fact, the marketing intelligence system determines what kind of intelligence is needed and receives it from the environment and provides it to the organization (Cutler \& Clare, 2006). Marketing intelligence is not just market research; it is practical intelligence to help managers of the organization. On the other hand, like all management activities and concepts, this activity should also be carried out by experts in organizations and companies. Individuals who must not only have specific marketing expertise and skills but also have effective individual characteristics to successfully implement this system (Bartlett \& Gashall, 2002).

\section{- IQ:}

IQ is briefed as intelligence quotient, which means intelligence ratio. Psychologists use a simple formula to calculate IQ, in which the subject's age formula is divided by his age and then multiplied by 100 . If we want to simplify this formula a little, we can say that if one's mental ability is quite equal to one's peers age range, his / her IQ will be equal to 100 . 
Of course, being slightly above or below the 100 mark of higher or lower intelligence cannot be considered, and experts are very cautious about interpreting the obtained number. In fact, they usually regard the 90 to 109 grade point average as average intelligence. Psychologists, of course, have reasons for this.

\section{- Creativity:}

Creativity means presenting new ideas and designs to improve the quantity or quality of an organization's activities, such as increasing productivity, increasing products or services, reducing costs, better products or services, new products or services, and so on.

\section{- Information:}

Information refers to any type of data collected using various methods such as: study, observation, gossip, and more. In the word "information", there is no pre-defined meaning in relation to the quality, validity or accuracy of the data, and there will be the possibility of dealing with valid, untrustworthy, factual, inaccurate, inaccurate and misleading information (Zarepour, 2008).

\section{- $\quad$ Emotional Intelligence:}

Emotional intelligence encompasses a wide range of individual skills and traits, usually referred to as interpersonal and interpersonal skills that go beyond a specific domain of prior knowledge, intelligence, and technical or professional skills (Sobhani Nejad, 2008).

\section{Literature Review}

According to Faryabi Mohammad et al. (2011), the results of the study of the review on an effect of individual characteristics on the creation of marketing intelligence in the organization (scientific centers and manufacturing and service companies of Tehran) indicate that the individual characteristics include personality, creativity and motivation. Intelligence and organizational posture are effective in creating marketing intelligence in the organization. Mohammad Moradi Rima (2011) assessing the impact of marketing intelligence on customer loyalty in industrial and industrial units of East Azarbaijan province (working in Industrial Management Organization) considered four individual, environmental, organizational and 
extra-organizational factors were considered for marketing intelligence. Customer loyalty was measured using a questionnaire and statistical analysis.

Jalali Koldeh (2009), in explaining and formulating a model for marketing intelligence creation, considered three organizational, personal and environmental factors for marketing intelligence creation. Individual factors including personality, creativity, motivation and organizational posture influence on intelligence. Organizational factors and processes including organization mission, organization vision, organization goals, organization structure, organizational management style, organization culture, organization resources and marketing research process all influence the formation of marketing intelligence. Economic, political, legal, cultural, social and technological factors influence the formation of marketing intelligence and the environmental factor does not influence the formation of marketing intelligence in the organization.

According to Gomeso Flasher (2001), the results of the research of executives 'perception of marketing intelligence value suggest that individual, environmental, organizational factors have a direct impact on managers' perception of marketing intelligence value and also this value affects the organization's performance.

Karayani (2006) conducting a study entitled "The Impact of Culture on Creating Marketing Intelligence" examined the relationship of intelligence gained through the Internet and its value creation and variables such as customer relationship, innovation, productivity and efficiency and the extent of these communications.

Wright \& Calif (2006), in the search for marketing, competitive, and business intelligences, examined the organizations' intelligence in terms of the process and structure, culture, knowledge, and attitude of the competitive intelligence cycle.

According to Fletcher (2008), the results of using open source to develop marketing intelligence and competitive intelligence indicated that open source is very useful for marketing intelligence professionals because they can easily access it. They are not expensive and are quickly accessible.

According to Matthew Hurlia \& Nick Achilles (2011), results of research, market intelligence and the success of new project development, found that managers rely on two types of intelligence, technical production and market information as well as most of the variables known to have a positive and direct relationship to Projects have success.

According to Yang Lee and Peter Trim (2006), the results of research on the role of marketing intelligence, relational marketing and trust, suggest that marketing intelligence is a key element 
in achieving the goal of why expensive retail strategies need to be developed. Long-term is based on trust.

Kakyolati et al. (2013) conducted a research of marketing intelligence in SMEs; the results indicate that organization size, strategic approach and organizational resources are catalytic for information use. Given the increasing importance of marketing intelligence and business intelligence in competitiveness, this study seeks to examine the organization's intelligence in facilitating and accelerating the acquisition of competitive advantage and enhancing competitiveness. Superiority over competitors and the acquisition of a competitive advantage are sustained in the conceptual paradigm. Considering the issues rose in the theoretical framework and summarizing the status of independent and dependent variables, the overall model of the research is plotted in Figure 1.

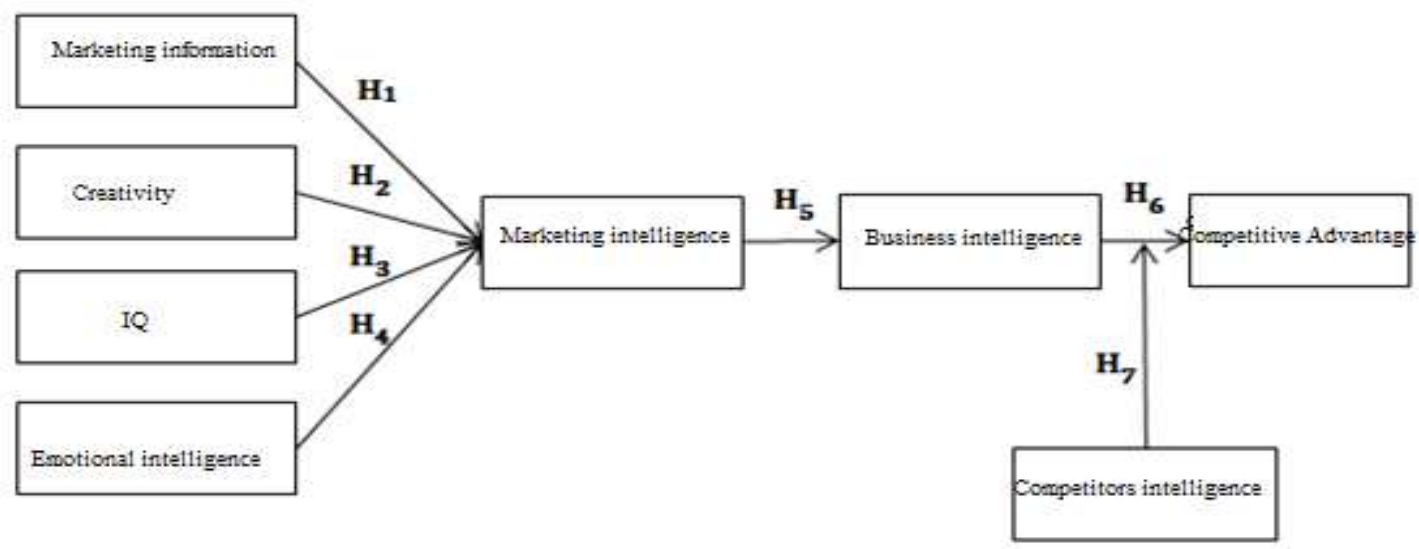

Fig 1. The research conceptual model

\section{Research hypotheses}

Hypothesis 1: Marketing information affects increased marketing intelligence.

Hypothesis 2: Creativity affects increased marketing intelligence.

Hypothesis 3: IQ affects increased marketing intelligence.

Hypothesis 4: EQ affects marketing intelligence

Hypothesis 5: Marketing intelligence affects business intelligence. 
Hypothesis 6: Business intelligence affects the acquisition of competitive advantage in drug distribution.

Hypothesis 7: Competitors' intelligence moderates the impact of business intelligence on gaining competitive advantage (moderator variable).

\section{Methodology}

The study is an applied, descriptive and survey research in terms of object, data collection, respectively. The statistical population of this study is managers of IT companies. At the forefront of any study or research is the question of how large the sample size should be; sample selection larger than needed results in resource loss and selection of very small samples results in unreliable results. A very important question in factor analysis and structural equation modeling is determining the minimum sample size (Klein, 2011; McKittie, 2004). Although there is no general agreement on the sample size required for factor analysis and structural models (Schreiber, 2006), many researchers say the minimum sample size is 200 (Holter, 1983; Garver \& Mentzer, 1999; Sievo et al., 2006; Ho, 2008) because this study is based on structural equation modeling, therefore, 200 people were selected as the minimum statistical sample and the questionnaire was distributed randomly among the sample. The data collection methods in this study are divided into two categories: library and field. Library methods were used to collect information on the subject literature and research background and field method was used to gather information to confirm or reject the research hypotheses. A questionnaire was used to collect the initial data. The research questionnaire was developed based on seven constructs of marketing information, creativity, IQ, emotional intelligence, marketing intelligence, business intelligence, competitors intelligence, competitive advantage. Content validity (expert opinion) and construct validity (factor analysis) were used to check the validity of the questionnaire. Cronbach's alpha coefficient was also calculated for reliability. Cronbach's alpha coefficient was 0.871 . Therefore, the reliability of the questionnaire was evaluated as desirable.

\section{Results}

Descriptive statistics show that out of the 200 managers selected as the sample, 156 are male and 44 are female. By age, 30 people are less than 30 years old, 58 subjects are aged between 30 to 40 years old, 60 are between 40 and 50 years old and 52 are over 50 years old. There are 
121 undergraduate degrees, 61 graduate degrees, and 18 doctoral degrees. In terms of work experience, 44 people have less than 5 years of management experience, 45 have between 5 and 10 years of management experience, 52 have 10 to 20 years of experience, and 59 have over 20 years of management experience. To investigate the model, confirmatory factor analysis was first used to measure the relationships of hidden variables with their measurement items. The measurement model (confirmatory factor analysis) examines the relevance of the items or the same questionnaire questions to the constructs. In fact, unless the markers or questionnaire questions have measured the hidden variables well, the relationships cannot be tested. Therefore, confirmatory measurement model or factor analysis is used to prove that concepts are well measured. The power of the relationship between the factor (hidden variable) and the variable visible is represented by the factor load. The factor load is a value between zero and one. If the factor load is less than 0.3 , the weak relationship is considered and ignored (Foster et al., 2006: 82). An operating load of between 0.3 and 0.6 is acceptable and if it is greater than 0.6 it is highly desirable. The least acceptable factor load in some sources and references is 0.2 , but the main criterion for judging $t$ statistics. If the test statistic means $t$ statistic is greater than the critical value of t0.05 ie 1.96, then the observed factor load is significant (Klein, 2011). The results of the factor analysis of the measurement variables of the research variables are presented in the following table. 


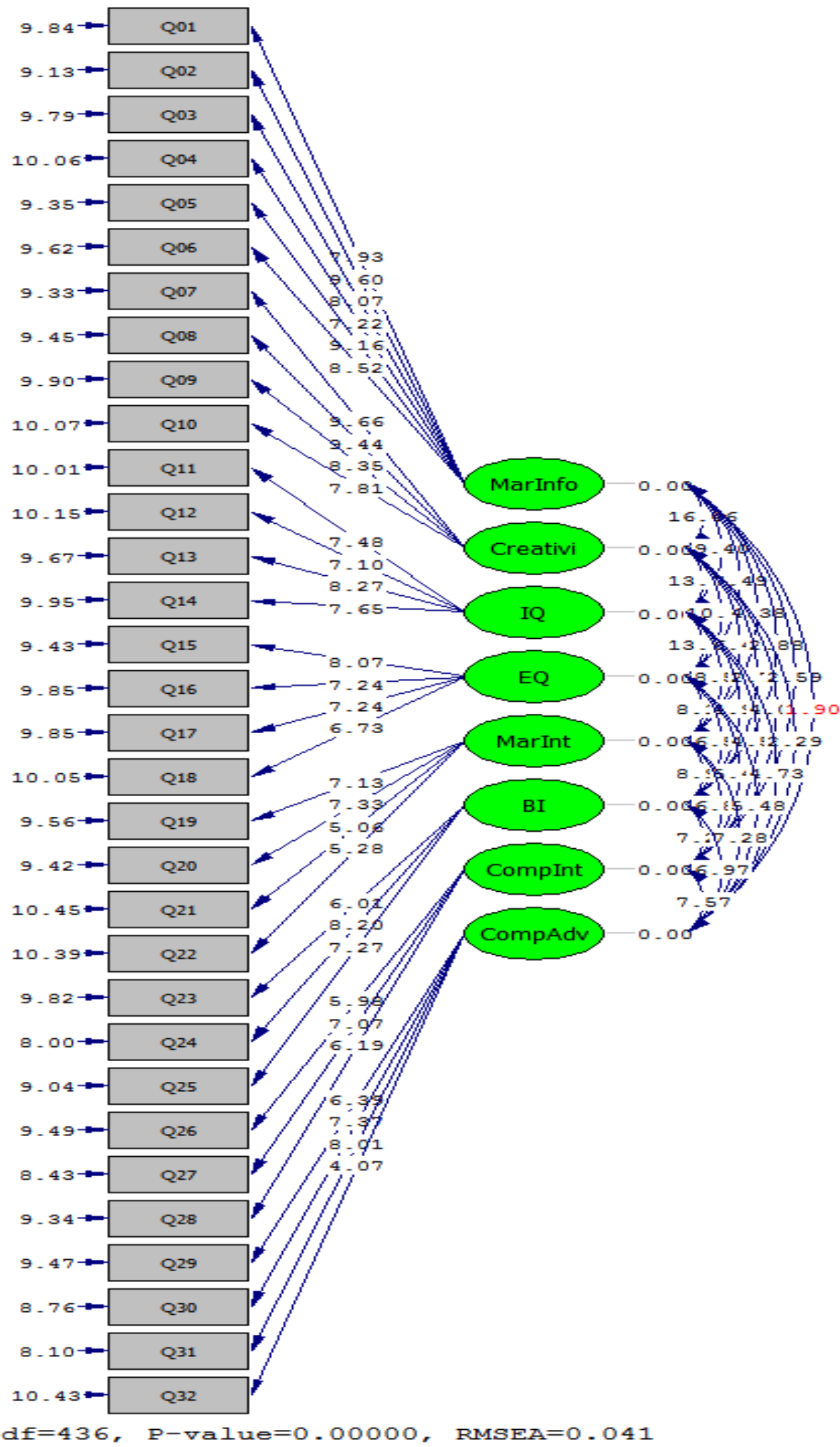

Thi-Square=615.48, $d f=436$, P-value=0. OOOOO, RMSEA=0.041 


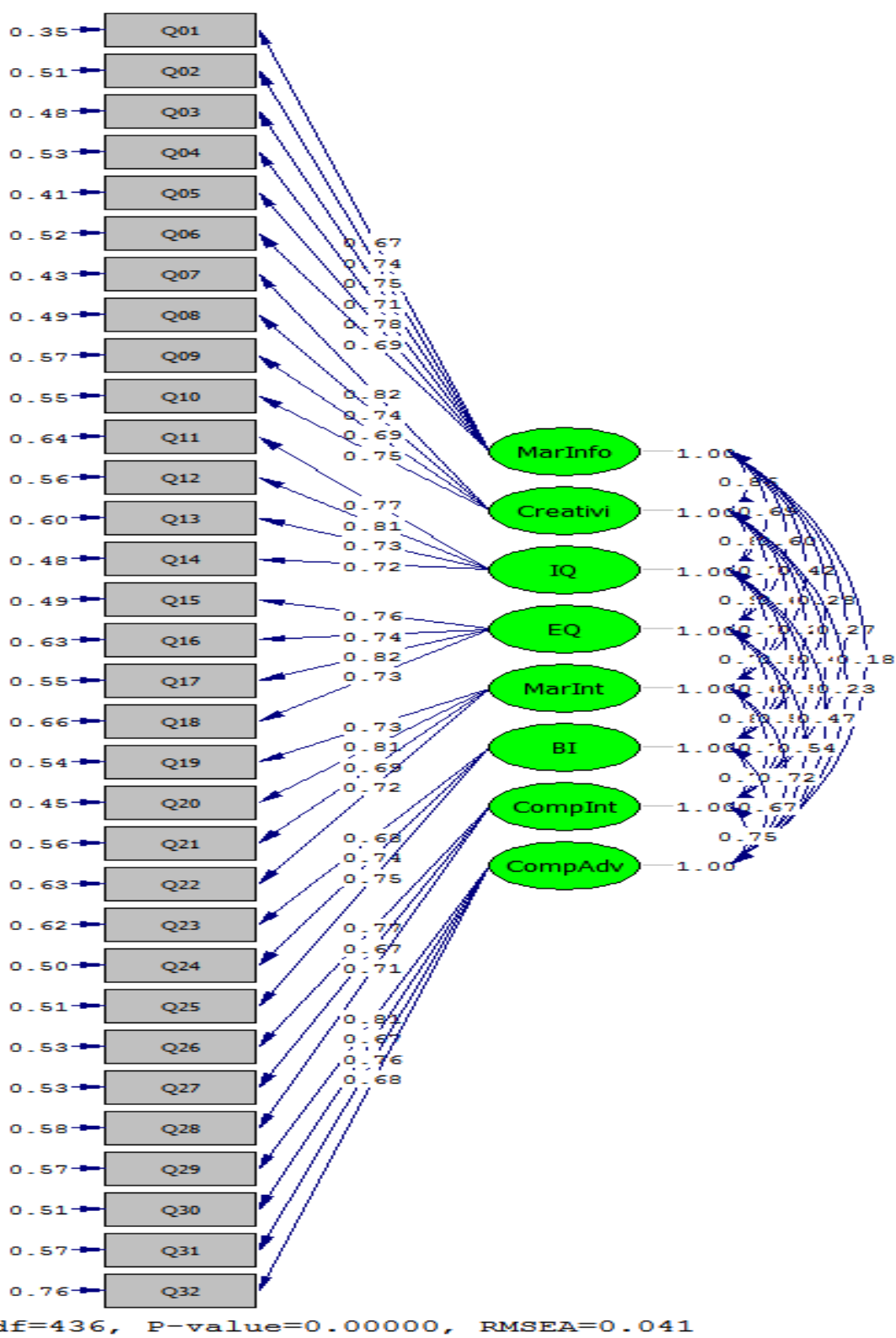

Fig 2. Confirmatory factor analysis 
Table 1.

Confirmatory factor analysis of the scale of research structures measurement

\begin{tabular}{|c|c|c|c|c|c|c|}
\hline Factors & Variables & Factor load & $\begin{array}{c}\text { Test } \\
\text { Statistics }\end{array}$ & AVE & $\mathrm{CR}$ & $\alpha$ \\
\hline \multirow{6}{*}{$\begin{array}{l}\text { Marketing } \\
\text { Information }\end{array}$} & Q01 & 0.67 & 7.93 & \multirow{6}{*}{0.524} & \multirow{6}{*}{0.868} & \multirow{6}{*}{0.863} \\
\hline & $\mathrm{Q} 02$ & 0.74 & 9.60 & & & \\
\hline & Q03 & 0.75 & 8.07 & & & \\
\hline & Q04 & 0.71 & 7.22 & & & \\
\hline & Q05 & 0.78 & 9.16 & & & \\
\hline & Q06 & 0.69 & 8.52 & & & \\
\hline \multirow{3}{*}{ Creativity } & Q07 & 0.82 & 9.66 & \multirow{3}{*}{0.565} & \multirow{3}{*}{0.838} & \multirow{3}{*}{0.763} \\
\hline & Q08 & 0.74 & 9.44 & & & \\
\hline & Q09 & 0.69 & 8.35 & & & \\
\hline & Q10 & 0.75 & 7.81 & & & \\
\hline \multirow{4}{*}{ IQ } & Q11 & 0.77 & 7.48 & \multirow{4}{*}{0.575} & \multirow{4}{*}{0.844} & \multirow{4}{*}{0.741} \\
\hline & Q12 & 0.81 & 7.10 & & & \\
\hline & Q13 & 0.73 & 8.27 & & & \\
\hline & Q14 & 0.72 & 7.65 & & & \\
\hline \multirow{4}{*}{$\begin{array}{l}\text { Emotional } \\
\text { intelligence }\end{array}$} & Q15 & 0.76 & 8.07 & \multirow{4}{*}{0.583} & \multirow{4}{*}{0.848} & \multirow{4}{*}{0.732} \\
\hline & Q16 & 0.74 & 7.24 & & & \\
\hline & Q17 & 0.82 & 7.40 & & & \\
\hline & Q18 & 0.73 & 6.73 & & & \\
\hline \multirow{4}{*}{$\begin{array}{l}\text { Marketing } \\
\text { intelligence }\end{array}$} & Q19 & 0.73 & 7.13 & \multirow{4}{*}{0.546} & \multirow{4}{*}{0.827} & \multirow{4}{*}{0.721} \\
\hline & Q20 & 0.81 & 7.33 & & & \\
\hline & Q21 & 0.69 & 5.06 & & & \\
\hline & Q22 & 0.72 & 5.28 & & & \\
\hline \multirow{3}{*}{$\begin{array}{c}\text { Business } \\
\text { intelligence }\end{array}$} & Q23 & 0.68 & 6.01 & \multirow{3}{*}{0.524} & \multirow{3}{*}{0.767} & \multirow{3}{*}{0.706} \\
\hline & Q24 & 0.74 & 8.20 & & & \\
\hline & Q25 & 0.75 & 7.27 & & & \\
\hline \multirow{3}{*}{$\begin{array}{l}\text { Competitor's } \\
\text { intelligence }\end{array}$} & Q26 & 0.77 & 5.98 & \multirow{3}{*}{0.515} & \multirow{3}{*}{0.761} & \multirow{3}{*}{0.711} \\
\hline & Q27 & 0.67 & 7.07 & & & \\
\hline & Q28 & 0.71 & 6.19 & & & \\
\hline \multirow{4}{*}{$\begin{array}{l}\text { Competitive } \\
\text { advantage }\end{array}$} & Q29 & 0.81 & 6.39 & & & \\
\hline & Q30 & 0.67 & 7.37 & & & \\
\hline & Q31 & 0.76 & 8.01 & 0.536 & 0.821 & 0.812 \\
\hline & Q32 & 0.68 & 4.07 & & & \\
\hline
\end{tabular}

The confirmatory factor analysis results in Table 1 show that the measurement items for each of the research dimensions are correctly selected. In all cases the standard factor load greater than 0.3 indicating that the observed correlation is optimal. The t-statistic was calculated to evaluate the significance of standard operating loads observed. In all cases the t-statistic was greater than 1.96, indicating that the observed correlations at 95\% confidence level are acceptable. 
- $\quad$ Testing research hypotheses using structural equation modeling

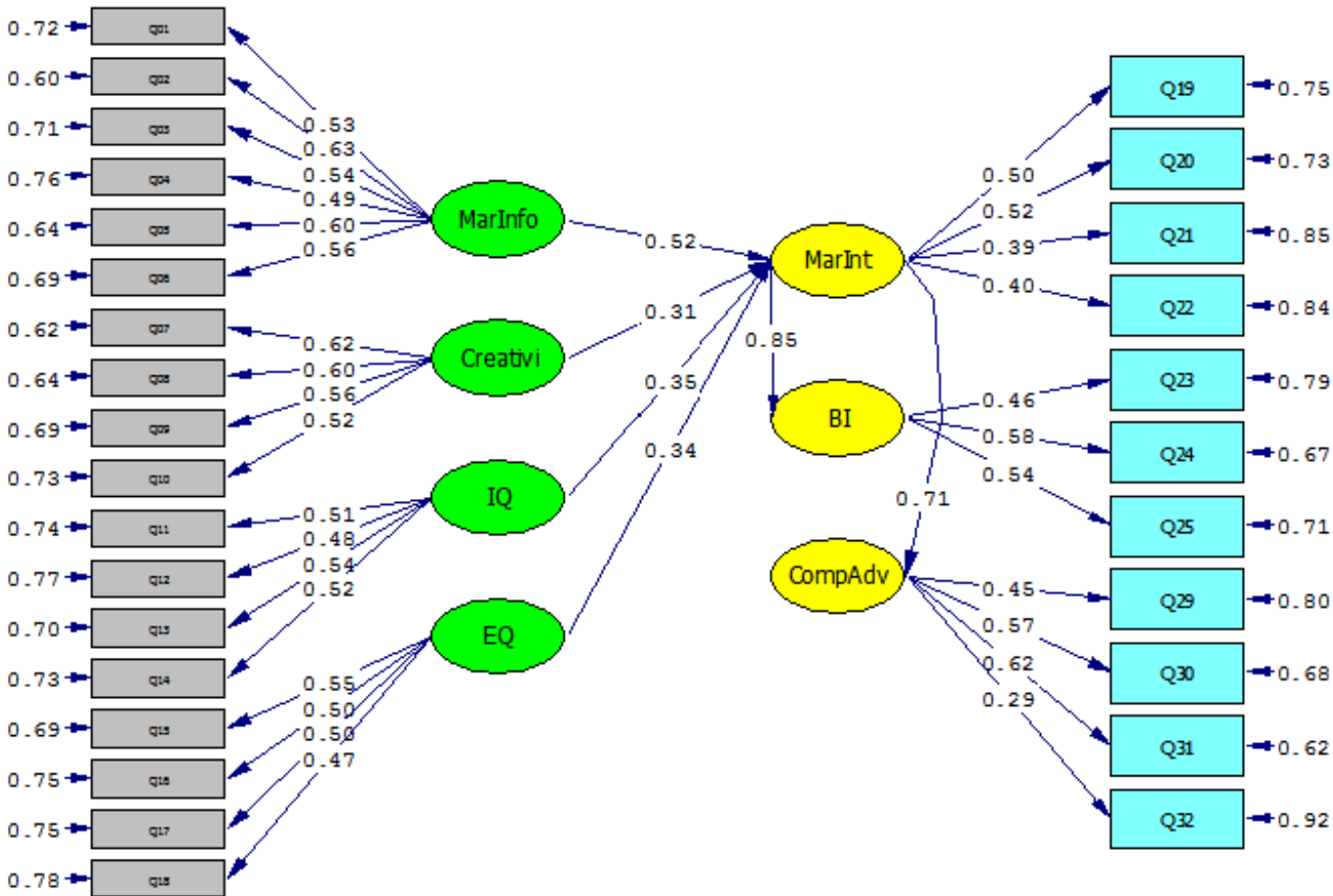

Chi-Square $=533.17, \mathrm{df}=365, \mathrm{P}-\mathrm{value}=0.00000, \mathrm{RMSEA}=0.044$

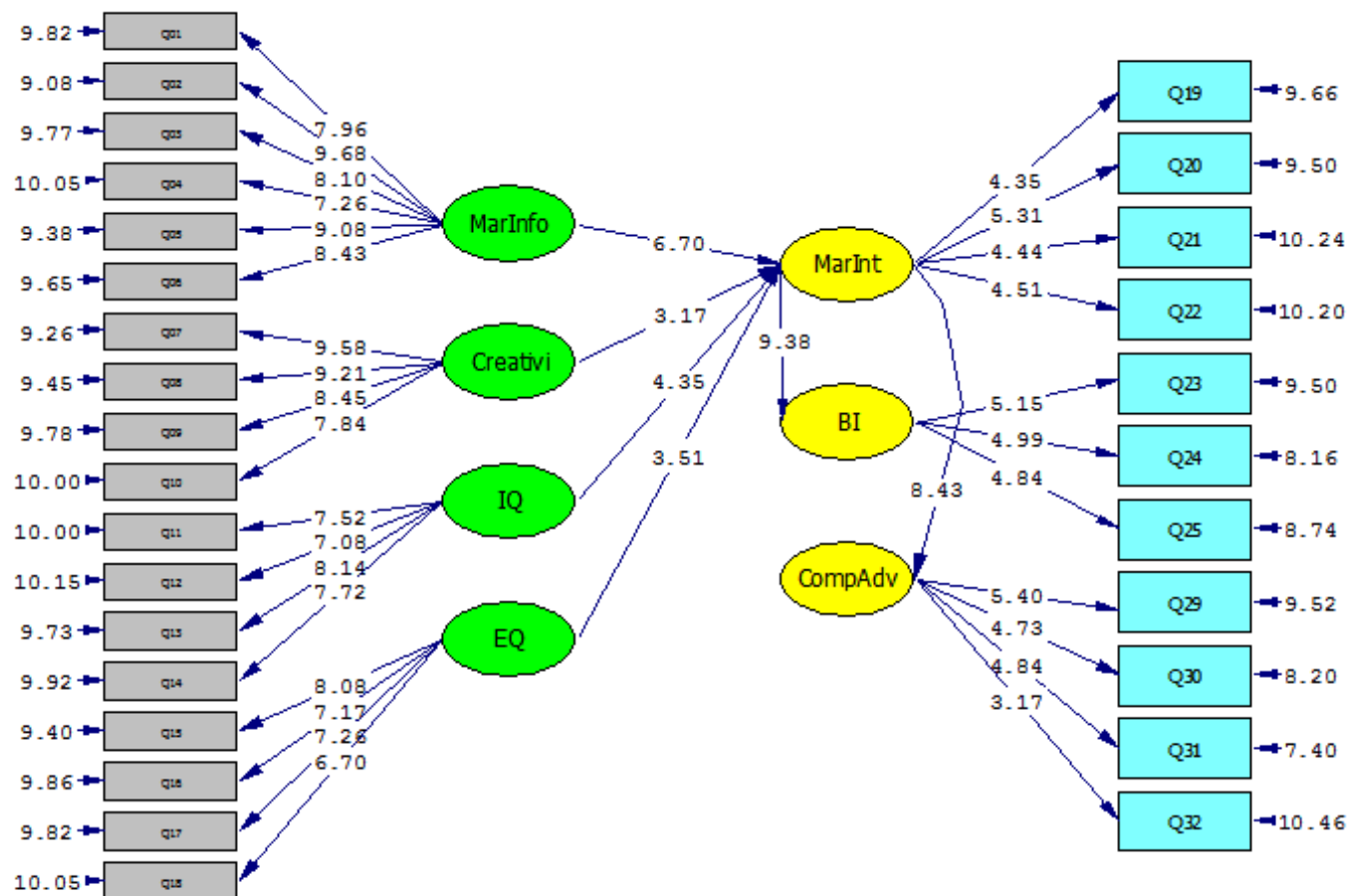

Chi-Square $=533.17, \mathrm{df}=365, \mathrm{P}-\mathrm{value}=0.00000, \mathrm{RMSEA}=0.044$

Figure 3. Structural Model 
Structural equation modeling was used to measure the overall relationship of the elements influencing customers' intention to use internet banking. The results are summarized in the output of LISREL software. These results are shown in Table 2.

Table 2.

Summary of Structural Equation Modeling Results

\begin{tabular}{|c|c|c|c|c|c|}
\hline $\begin{array}{l}\text { Independent } \\
\text { Variable }\end{array}$ & $\begin{array}{c}\text { Independent } \\
\text { Variable }\end{array}$ & $\begin{array}{l}\text { Dependent } \\
\text { Variable }\end{array}$ & Factor load & T-statistics & Result \\
\hline Hypothesis 1 & $\begin{array}{l}\text { Marketing } \\
\text { information }\end{array}$ & $\begin{array}{c}\text { Marketing } \\
\text { intelligence }\end{array}$ & 0.52 & 6.70 & Confirmed \\
\hline Hypothesis2 & Creativity & $\begin{array}{l}\text { Marketing } \\
\text { intelligence }\end{array}$ & 0.31 & 3.17 & Confirmed \\
\hline Hypothesis 3 & IQ & $\begin{array}{c}\text { Marketing } \\
\text { intelligence }\end{array}$ & 0.35 & 4.35 & Confirmed \\
\hline Hypothesis 4 & $\begin{array}{l}\text { Emotional } \\
\text { intelligence }\end{array}$ & $\begin{array}{c}\text { Marketing } \\
\text { intelligence }\end{array}$ & 0.34 & 3.51 & Confirmed \\
\hline Hypothesis 5 & $\begin{array}{l}\text { Marketing } \\
\text { intelligence }\end{array}$ & $\begin{array}{c}\text { Business } \\
\text { intelligence }\end{array}$ & 0.85 & 9.38 & Confirmed \\
\hline Hypothesis 6 & $\begin{array}{c}\text { Business } \\
\text { intelligence }\end{array}$ & $\begin{array}{l}\text { Competitive } \\
\text { Advantage }\end{array}$ & 0.71 & 8.43 & Confirmed \\
\hline
\end{tabular}

The standard factor load of the impact of marketing information on marketing intelligence was 0.52 . The t-statistic value is also 6.70 , greater than the critical value of 1.96 . Therefore, 95\% confidence can be asserted: Hypothesis 1 is confirmed.

The standard factor load of creative influence on marketing intelligence was 0.31 . The t-statistic value is also 3.17 , greater than the critical value of 1.96 . Therefore, $95 \%$ confidence can be asserted: Hypothesis 2 is confirmed.

The standard factor load of the impact of IQ on marketing intelligence was 0.35. Also the t-statistic value is 4.35 , greater than the critical value of 1.96 . Therefore, $95 \%$ confidence can be asserted: Hypothesis 3 is confirmed.

The standard factor effect of emotional intelligence on marketing intelligence was 0.34 . The tstatistic value is also 3.51, greater than the critical value of 1.96 . Thus, it can be safely asserted: Hypothesis 4 is confirmed.

The standard factor effect of marketing intelligence on business intelligence was 0.85 . The t-statistic was also 9.38, greater than the critical value of 1.96 . Therefore, $95 \%$ confidence can be asserted: Hypothesis 5 is confirmed.

The standard factor load of business intelligence on competitive advantage was 0.71 . The t-statistic was also 8.43 , greater than the critical value of 1.96 . Therefore, $95 \%$ confidence can be asserted: Hypothesis 6 is confirmed. 


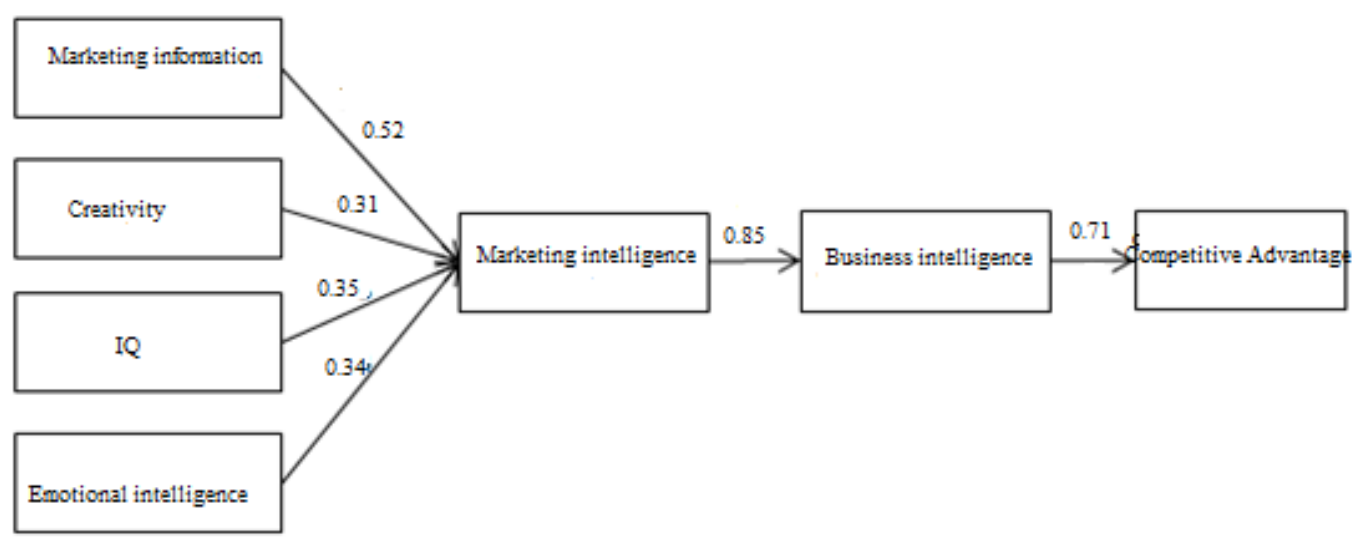

Figure 4. The result of the structural model of the research

Based on the conceptual model of Structural Research, the competitive intelligence in this study has played a moderating role on the relationship between "business intelligence" and "competitive advantage". Based on the hypothesis of seven competitors intelligence, moderates the impact of business intelligence on the acquisition of competitive advantage. In this study, people's perspectives on competitors' intelligence were investigated with a 5-point Likert scale questionnaire. If the midpoint of 3 is considered to be an average, competitors' intelligence is divided into two categories: those whose average score is above 3 rated their competitors' intelligence high and those whose average score is three or less rated their competitors' intelligence poor. 68 people (34\%) are among those who rated competitors poor and $132(66 \%)$ highly rated competitors. The structural model is implemented separately for each group. If we show the business intelligence structure with $\mathrm{X}$ and the competitive advantage with $\mathrm{Y}$, then the following results are broken down into groups:

Structural Equations (All)

$\mathrm{Y}=0.71 * \mathrm{X}\left(\right.$ Errorvar. $\left.=0.31, \mathrm{R}^{2}=0.56\right)$

Structural Equations (High)

$\mathrm{Y}=0.77 \mathrm{X} ;$ Errorvar. $=0.31, \mathrm{R}^{2}=0.86$

Structural Equations (Low)

$\mathrm{Y}=0.27 * \mathrm{X} ;$ Errorvar. $=0.31, \mathrm{R}^{2}=0.44$

Based on the above equations, it is clear that the impact of business intelligence $(\mathrm{X})$ on competitive advantage (Y) is higher among those who rated competitors higher than those who rated competitors poor. 


\section{Discussion and Conclusions}

In this study, the impact of marketing intelligence and business intelligence on the acquisition of competitive advantage was analyzed. Structural equation modeling and LISREL software were used to evaluate the relationship between research variables. The results show that companies, information (type of information, frequency of use, information sources), creativity and IQ have positive and significant effect on marketing intelligence and marketing intelligence has positive effect on business intelligence. And it makes sense, and as a result, business intelligence has a positive and meaningful effect on the acquisition of competitive advantage by considering the variable role of competitors' moderating intelligence. In general, this study confirms the relationship between model variables.

- While analyzing the relevant data, it is recommended that:

- Paying a great attention to information in marketing management. The managers should not only seek to conduct marketing research and gather a wealth of sometimes unhelpful information, but must also provide practical and usable intelligence for their organization by summarizing information and interpreting it accurately.

- Organizations need to create ethics in their organization in order to gain marketing intelligence. This means that if an organization is creative, it will definitely have a positive impact on building marketing intelligence in that organization.

- Employees' personal intelligence factor, the most important of which is emotional intelligence and then IQ, has a great impact on the marketing intelligence.

- Using all components of marketing intelligence and marketing research and with the support of managers and monitoring the performance of the company, in order to identify the needs and desires of the clients, strengths and weaknesses of competitors and optimize the web and business marketing activities and thus Gain competitive advantage.

- Today, applied some concepts such as business intelligence is very important to playing a role in organizational decision-making and productivity enhancement and to acquiring a competitive advantage in different industries. A business intelligence system promotes the value of information at the beginning of an information chain. Using different technologies, it collects and structures data and converts it into information. Therefore, it is suggested to improve the information flow in the organization by deploying and applying business intelligence system in different ways. Because, identifying and evaluating the factors that 
influence the performance and performance of business intelligence systems in an organization is crucial.

- Playing an effective role in addressing the competitiveness of the company by addressing competitiveness weaknesses in the field of marketability by responding to competitors' actions, identifying competitor strategies and identifying market opportunities based on competitiveness.

\section{References}

Adidam, P. Sampada, G and Kejriwal, S. (2009). "Cross-cultural competitive Intelligence Strategies", Marketing Intelligence \& Planning, Vol. 27 No. 5, pp. 666-680.

Bartlett, C and Ghoshal, S. (2002). "Building competitive advantage through people", MIT Sloan Management Review, Winter, p. 30- 43.

Edwards, Jeffry; Lambert, Lisa. (2007). Methods for Integrating Moderation and Mediation: AGeneral Analytical Framework Using Moderated Path Analysis,' Psychological Methods, $12,1,1$.

Farabi, Mohammad et al. (2011). "Investigating the Effect of Individual Attributes on Marketing Intelligence Creation in the Organization under Study, Scientific Center and Manufacturing and Service Companies of Tehran", Modern Marketing Research Journal, Vol. 1, No. 1.

Fleisher C.S. (2008). using open Source data in developing competitive and marketing intelligence, European journal of Marketing, Vol.42,No,7/8,PP.652-660.

Fleisher C.S;Wright S \& Tindale R. (2007). A chronological and categorized bibliography of key competitive intelligence scholarship:part A(2003-2006), journal of competitive intelligence and management,Vol.4,No.1,PP.34-107.

Fornell, Claes; Larcker, David. (1981). Evaluating Structural equation models with unobservable variables and measurement error, Journal of Marketing Research, Vol. 18, No. 3, Pp. 39-50.

Foster, Jeremy; Barkus, Emma; Christian, Yavorsky. (2006). Understanding and using advanced statistics, London: SAGE, ISBN: 141290014X, 9781412900140.

Garver, Michael; Mentzer, John. (1999). Logistics research methods: Employing structural equation modeling to test for construct validity, Journal of Business Logistics, Vol. 20, No, 1, pp. 33-57.

Grooms, T and Fletcher, S. (2001). "Marketing Intelligence, Executive Management Perceptions of Value", Marketing Intelligence \& Planning, Vol. 19.No. 4. pp.241-257.

Hair, Joseph; Black, William; Babin, Barry; Anderson, Rolph. (2010), Multivariate data analysis (7th ed.). New Jersey: Pearson prentice Hall.

Hoe, Siu-Loon. (2008). Issues and procedures in adopting structural equation modeling technique, journal of applied quantitative methods, vol 3, no1. pp 76-83.

Hoelter, John. (1983). The analysis of covariance structures: Goodness-of-fit indices, Sociological Methods and Research, Vol. 11, No. 3, pp. 325-344.

Jackson, Dennis. (2003). Revisiting sample size and number of parameter estimates: Some support for the hypothesis. Structural Equation Modeling, 10, 128-141. doi:10.1207/S15328007SEM1001_6. 
Jalali Kalde, Alireza. (2009). "Explaining and Developing a Model for Marketing Intelligence", M.A Thesis of Business Management, Aras Institute of Higher Education.

Jöreskog, Karl; Sörbom, Dag. (2001). LISREL: Structural Equation Modeling with the simplis command language, Uppsala university, Scientific Software International Inc, ISBN089498-049-1.

Karayanni, A. (2006). The effect of culture on creation Marketing intelligence by internet and creation value in organization, Journal of Strategy \& Leadership, VOL. 30 NO. 2.

Kline, Rex. (2011). Principles and Practice of Structural Equation Modeling (Methodology in the Social Sciences), New York: Guilford Press, 3rd Edition. ISBN-13: 978-1606238769.

Kotler, P. \& K. L. Keller. (2006). Marketing Management, 12th Edition, Upper Saddle River, NJ: Prentice Hall.

MacCallum, Robert; Browne, Mooli; Sugawara, Hazuki. (1996). Power analysis and determination of sample size for covariance structure modeling. Psychological Methods, $1,130-149$.

Mahmoodi, M. (2005). Business Intelligence Systems a Key for Managers, Journal of Management, No. 135.

McQuitty, Shaun. (2004). Statistical power and structural equation models in business research, Journal of Business Research, Vol. 57, No. 2, pp. 175-183.

Mohammad Moradi, Rima. (2011). "Investigating the Impact of Marketing Intelligence on Customer Loyalty", M.A Thesis of Executive Management, Aras International Campus, Tabriz University.

Schreiber, James; Nora, Amaury; Stage, Frances; Barlow, Elizabeth; King, Jamie. (2006). Reporting structural equation modeling and confirmatory factor analysis results: A review, Journal of Educational Research, Vol. 99, No. 6, Pp. 323-337.

Schumacker, Randall; Richard, Lomax. (2010). A beginner's guide to structural equation modeling Publisher: Routledge; 3 edition (April 23).

Shah, Rachna; Goldstein, Susan. (2006). Use of structural equation modeling in operations management research: Looking back and forward, Journal of Operations Management, 24, 148-169. doi:10.1016/j.jom.2005.05.001.

Sivo, Stephen; Fan, Xitao; Witta, Lee; Willse, John. (2006). The Search for 'Optimal' Cutoff Properties: Fit Index Criteria in Structural Equation Modeling, The Journal of Experimental Education, Vol. 74, No. 3, pp. 267-289.

Sobhani Nejad, Mehdi et al. (2008). "Emotional Intelligence and Management in Organization", Tehran Seatron Publications .

Wright, S and Calof, J. (2006). "Business and Marketing Intelligence " Journal of Competitive Intelligence" Vol. 40 No .5 .pp. 453-465. 